\title{
Occupational Attributes With The Highest Minority Domination: Variables Narrowing Or Increasing Interethnic Occupational Differences
}

\author{
Annabel Droussiotis (E-mail: annabel@lim.intercollege.ac.cy), Intercollege Cyprus
}

\begin{abstract}
The occupational profile of the various ethnic groups varies in the United States. The occupational stratification is sometimes based on one's ethnicity rather than ability. When interethnic occupational differences are attributed to discrimination the result is inefficiency in the labor market. The purpose of this study is to determine the occupations in which ethnic minorities are dominant and the factors which are most significant in either increasing or reducing this dominance. The data consist of 183 Economic Areas (as defined by the Bureau of Economic Analysis). Explanatory variables reflect educational levels, human capital accumulation, social status, government action, and general area characteristic for each groups. Occupational attributes are used to aggregate all occupations, reflecting prestige and satisfaction levels. African-American, Hispanic-American and Asian-American groups are compared to nonHispanic whites. Males and females are tested separately. The results show that African American and Hispanic males and females are influenced by similar variables. The level of higher education assists the labor position of African and Hispanic American males reducing interethnic occupational differences. The density of the minority group in the area improves the position of their female counterparts. The Asian American group is very different.
\end{abstract}

\subsection{Introduction}

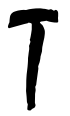

he population of the United States is quite diverse. Women make up 50.9 per cent. Hispanic Americans make up 12.5 percent followed by African Americans who make up 12.3 percent. Asian Americans comprise only 3.6 percent of the U.S. population. (U.S. Department of Labor, 2002). The labor force participation is also quite diverse. Women make up 46.5 percent of the Civilian Labor Force (CLF), African Americans 11.3 percent (Prywes, 2000) and Hispanic Americans 11.8 percent (Guadalupe, 2002). Asians are less. The Hispanic American group is the fastest growing.

The heterogeneity of the Labor force, however, is not without costs. Minority groups experience occupational stratification, wage-differentials and stereotyping.

Minorities are unevenly distributed across industries and occupations as well as job categories. Some occupations are considered male or female while other occupations are considered black. For example, gender segregation channels women in child-care, and care taking occupations (nursing, teaching). Economic forces are also unfavorable to minorities. In the case of the reduction of agriculture, men where driven into industry positions and women were driven out of factory positions where they were considered cheap and docile. Generally, females and ethnic minorities are not often found at higher-level positions and are not given positions of authority (Prywes,

Readers with comments or questions are encouraged to contact the author via email.

2000). Women in large organization are usually hired for positions with no prospects for career or promotion, while 
positions with good prospects are given to men (Sorensen, 1989). Minorities are faced with barriers for advancement discriminated in both hiring and promotions and are overall clustered in lower status occupations (Frey and First, 1997). The representation of minorities in occupations that require a university degree (scientific labor force) is far below their representation in the total U.S. population. In academia, minorities are less likely to receive tenure, receive lower salaries, fewer publications and less funding (Jones, 2002). Certain minority groups hold primarily many personal service occupations. Blacks are concentrated in low-paying service and blue-collar occupations (Amecher and Ulbrich, 1989). Glick et al (1995), suggest that people pursue jobs that match their socioeconomic background as well as popular stereotypes.

Minorities also receive inferior remuneration packages. Wage differentials are evident among women and minorities who are lacking behind their white male counterparts. Females are currently making 75 percent of what their male counterparts make and this figure is constantly decreasing. African American workers make 75 percent of their white counterparts and Hispanic American workers only 68 percent. What is interesting is that black females make 87 percent of their black male counterparts, while Hispanic American females make 86 percent of their male counterpart (Prywes, 2000). Female dominated occupations earn lower wages than male dominated occupations. A male working in a female dominated occupation would earn less than if occupied in a male dominated occupation (Sorensen, 1994). The wage differentials from the above segregation can be as high as 30 percent (Prywes, 2000). Sorensen (1994) believes that 23 percent of the gender wage differentials are due to occupational segregation.

There seems to be a dispute among economists as to what causes these differences among women and men or among ethnic minorities and whites.

Some economists believe the root and the cause of these differences is discrimination. Amacher and U1brich (1989) find discrimination to be responsible for $25 \%$ of interethnic earnings differences. The remaining $75 \%$ can be explained by differences in human capital, which could themselves be attributed to discrimination. Flückiger and Silber (1999) suggest that gender wage differentials are attributed by large (75\%) to discrimination. Discrimination brings about inefficiency and misallocation of resources. Denial of decent education, job training and generally discrimination in employment and housing hurt the whole society. Positions are filled with less than the best fitted people, while others are placed in occupations for which they are not qualified. Many potential gains available through specialization according to comparative advantage are lost and the total value of output is less than potential if performance alone was the prime employment criterion (Amacher and Ulbrich, 1989).

Other economists are reluctant to attribute the intergender and interethnic labor force differences to discrimination. Instead they attribute it to differences in human capital (Prywes, 2000). Heckman (1998) attributes most of the wage gap between blacks and whites to pre-market factors. Sokoloff (1992) suggests that human capital is the reason for the segregation since affirmative action and acquisition of college degrees have improved the position of minorities. Smith (2001) states that race wage gaps are due to differences in schooling, differences in quality of minority students, affirmative action and structural labor market changes. Geographical segregation in public schooling restricts access to good quality education (Kimenyi, 1995).

Socialization is another explanation for the job segregation. Smith and Welch (1987) suggest that the domestic role society places on women influence their decision to go into jobs where responsibility and stability are high. Also, blacks have taken advantage of the demand for well paying low-skill jobs in heavy industries. Hackim (2000) suggests that women look for a balance between work and family. She proposes there are three types of women. One who is work oriented, one who is adaptive and one who is home oriented. The existence of equal opportunities has allowed this to become more vivid. Myers (1989) and Schoepfle (1992) suggest that some of the unemployment among the African Americans is voluntary.

Finally, geographic and company characteristics influence the occupational channeling of ethnic minorities. Gardeck (2001) states that the characteristics of the neighborhood one resides in, affect the probability of employment. Blacks and Hispanics are more likely to be hired in areas where the race is not stereotyped. Similarly, Holzer and Inlanfeldt (1998) suggest that the ethnicity of a company's customers has a sizeable effect on who gets hired. The customers' ethnic origin influences particularly jobs that involve direct contact, sales or service occupations. 
What is interesting is that when the customers of an establishment are African American, the employees make less money than when the customers are white.

For the purpose of this paper, the initial causes of discrimination will be considered as exogenous. Discrimination is taken as an existing fact of the present society. This paper focuses on the occupational attributes that present the highest level of segregation for each ethnic group and attempts to determine which factors are the most important in either increasing or narrowing the most dispersed minority held occupational attribute.

\subsection{Following is a brief historical review of the minority groups tested.}

\subsection{African Americans}

Studies of the African American group find that three of the most important factors contributing to the improvement of the socioeconomic levels of blacks are: migration from the South, affirmative action, and education. Smith and Welch (1989) recognize migration as a mean for blacks to avoid discrimination and therefore to improve their socioeconomic level. They find that Blacks in the South earn thirty percent less than elsewhere. Bart (1987), and Smith and Welch (1989) interpret the effect of affirmative action as very effective for the improvement of African American citizens. In addition, education has enabled blacks to climb the corporate ladder and gain competitive human capital (Smith and Welch, 1989). In 1890, 61 percent of black adults were illiterate. In 1954, the U.S. Supreme Court outlawed school segregation and by 1961 the number of black illiterates dropped to four percent. In 1940, two percent of blacks had a baccalaureate degree. By 1975, the number rose to 11 percent. In 2000,11 percent of the blacks had a baccalaureate degree and almost four percent had received a masters degree. In addition, one in a thousand blacks had professional qualifications and the same number had received a doctorate. (Table 5, U.S. Census, Dec. 2000).

Today blacks are divided into three main social groups. The ones who have managed, despite the many drawbacks, to climb the socioeconomic levels and become specialized and productive citizens. The ones who are still in low-pay, low-skill jobs but who are living decently, though poorly; and the growing urban underclass, who is unemployed and will stay this way (Lehman, 1986). In this group are those who engage in criminal activities such as drug dealing, prostitution, and theft. Unemployment among the African American group is 10.2 percent, the highest of all ethnic groups (Dervarics, 2002).

\subsection{Hispanic Americans}

The Hispanic group is composed of many different cultures. Mexicans constitute 58.5 percent of the Hispanic population, Puerto Ricans constitute 9.6 percent, and Cubans just 3.5 percent (Wellner, 2002). All other subgroups are far less. For the empirical part of the paper, though, all Hispanics are included in the measurements. Hispanics differ in geographical regions (Mexicans are concentrated in the Southwest, Puerto Ricans in New York and urban areas, and Cubans in Florida, mostly in Miami), as well as in human capital accumulation. Therefore, it would have been preferred to study these subgroups separately. Due to the absence of data for Hispanic subgroups, however, all Hispanics are treated as one minority group.

The unstable political and economic situation of Mexico, forced many Mexicans to enter the U.S. illegally in the 1970s and 1980s. Official estimates calculate that five to ten million Mexicans are undocumented. Many believe that this number is highly exaggerated (Feagin, 1984).

Mexican-Americans have suffered a lot of ethnic discrimination in society, as well as, in the labor force. Because of lower wages, many Mexican-Americans are forced into urban ghettos. Then, too, as a result of accepting lower wages, many unions are against them, since employers often prefer them to whites (Feagin, 1984).

Puerto Ricans, unlike Mexicans, were mostly legal immigrants to the mainland. In 1980, more than two 
million Puerto Ricans had immigrated to the U.S. Today, this subgroup is the poorest minority group after Native Americans.

In 1980, Hispanic unemployment rose to 16 percent. In 2002, this rate was eight percent, the second largest minority unemployment rate after the African Americans (Dervarics, 2002). Teinda (1986) proposes that the color of the skin influences discrimination from one Hispanic subgroup to the next. For example, poverty rates for Mexicans rose to 22 percent, whereas poverty rates for Puerto Ricans rose to a significant 35 percent. The overall percentage of Hispanics below the poverty line is 25 percent (Wellner, 2002).

Hispanics are underrepresented in the federal government while they make up 11.8 percent of the civilian labor force, they account only for 6.6 percent in the federal work force (Guadalupe, 2002).

When comparing African to Hispanic Americans' educational attainment, there is an interesting distinction to be made. Blacks hold by far more baccalaureate and masters degrees; while Hispanics hold about the same professional and doctorate degrees (U.S. Census, Dec. 2000). Just over six percent of the Hispanic men and women hold a baccalaureate degree, and almost two percent have acquired a masters degree. One in a thousand hold professional qualifications and the same number holds a doctorate degree (Table 5, U.S. Census, Dec. 2000).

\subsection{Asian Americans}

Asian-Americans comprised three percent of the American population by 1990. They are the fastest growing minority group in the United States (Kim and Lewis, 1994). The U.S. Census Bureau (1992b) has assessed that Asian Americans may in fact comprise seven percent of the U.S. population.

Asian-Americans primarily settle in metropolitan areas. Ninety-four percent of this group lived in metropolitan areas. (Kim and Lewis, 1994). In addition, almost 56 percent of them are settled in the West (U.S. Census, 1994).

General opinion holds that Asians do not face high levels of discrimination compared to other minorities. However, this opinion does not hold true. The false perception may be attributed to the phenomenically high Asian family income, which is a result of a larger family size of Asian households and not higher earnings in comparison with others (Kim and Lewis, 1994). Even though Asian American males and females have higher levels of higher education than their white counterparts (Tables 1 and 5). Asian male college graduates earn only 90 percent of their white male counterparts, while Asian females are slightly better off, earning 95 percent of their white female counterparts (U.S. Census, 1992b). Discrimination is evident also in the types of occupations Asian Americans perform. Both males and females hold more professional positions, rather than administrative or managerial. It is suggested that this may result from discrimination by subordinates. Workers prefer to be under the supervision of white, rather than minority managers. (Kim and Lewis, 1994, and Xin, 1997). They also run into a glass ceiling in the corporate world (Cheng, 1997, and Bellinger, 1994). In addition, they enter professions such as law for the support of their co-ethnics (Klein, 1997).

Less-educated Asians face even more discrimination. A large majority of the less-educated Asian females are concentrated in textile and electronics industries, performing assembly line duties (Mason, 1986). Employers in these industries prefer Asian females because Asian women have always been considered quiet, obedient, and easily managed labor (Lutz, 1988,). This fact may explain why the occupational attribute "mechanical ability" is dominated by Asian females (a percent deviation of 85 percent).

\subsection{Methodology}




\subsection{Occupational Attributes}

Clymer and Mcgregor (1992) have constructed a methodology, one of few used by researchers, to aggregate the 512 occupational categories. The classification into attributes is borrowed from work directed at high school career guidance counselors. These attributes emerge as meaningful dimensions in which to describe occupations to young Americans concerned about issues such as work satisfaction and prestige. From the 18 attributes constructed by the authors, only 16 are used in this study. The ones excluded are "educational level" and "geographical concentration", which are used as explanatory variables. Using occupational attributes reflects more clearly the differences of the racial groups in their job activities. For example, are blacks predominately working in occupations which require repetition, part-time or physical stamina? Are whites predominant in jobs that require public contact, artistic talent or research and compiling?

\subsection{Economic Areas}

This study uses 183 U.S. Economic Areas (EA). Each EA is defined by the Bureau of Economic Analysis (United States Department of Commerce 1990), and consists of an important urban county surrounded by rural counties: e.g. downtown New York City and all the surrounding counties containing commuters to that area. The reason for using EAs versus counties or Metropolitan Statistical Areas (MSAs) is because there is almost no interEA mobility. At a county level, there is a lot of intercounty mobility, resulting in data problems since counties are open economies e.g. Some people live in a rural county and are working in the nearby urban county. The Bureau of Economic Analysis defines EAs as relatively self-contained local economies. This allows a wide range of data to be applied, including both demographic information (based on place of residence) and economic information (based on place of work). Explanatory variables contain both demographic and economic information.

\subsection{Ethnic Groups}

Minority ethnic groups are evaluated against white non-Hispanics. Minority groups used in this study are non-Hispanic African Americans, non-Hispanic Asian Americans and Hispanic Americans. Males and females are tested separately. So non-Hispanic African American males will be tested against non- Hispanic white males etc. The term African Americans and blacks will be used interchangeably referring to non-Hispanic African Americans. In addition Asians is used to refer to non-Hispanic Asians Americans, and whites refers to non-Hispanic whites. Whites are considered to be the least discriminated-upon group, therefore, all minority groups are compared against them. Comparison against this group will show patterns of discrimination. Males and females are tested separately to identify possible interethnic gender differences. Are black females influenced by different variables than black males?

\subsection{Dependent Variable}

In the United States, jobs are stereotyped. Certain occupations are predominantly held by AfricanAmericans whereas others are held by Hispanic, Asians or whites. Hispanics and African Americans seem to be predominant in occupational attributes that do not require high levels of education. Whites, in comparison, are predominant in white-collar jobs.

The following equation calculates the percent deviation between the ethnic group and the white group:

$$
A s, e-w=\frac{\frac{e s}{E}-\frac{w s}{W}}{\frac{w s}{W}}
$$

$\mathrm{e}_{\mathrm{S}} \quad=$ number of ethnic group tested in occupations with attribute $\mathrm{s}$ 


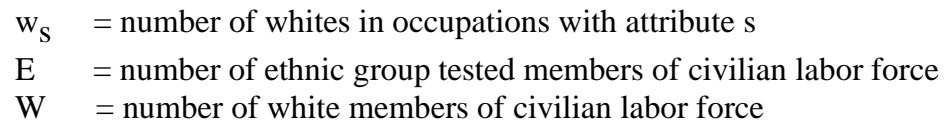

Table 1 shows the percent deviation of each ethnic group compared to whites for the U.S. as a whole. When the value is negative, the attribute is predominantly white. When the value is positive, the attribute is predominantly performed by the ethnic group.

The theory was developed by Eff, 1994 for intergender differences. This study uses the same approach to show interethnic differences.

This paper will focus on the largest positive number in each ethnic group and identify the significant factors influencing the percent deviation.

\subsection{Explanatory Variables}

All the explanatory variables used, reflect factors within each EA that may influence the occupational segregation of the ethnic groups. Table 2 presents the explanatory variables used. Below is the theoretical significance of each variable in the model:

- $\quad$ EDDIF $_{\mathbf{k}}$ compares the level of higher education of whites versus an ethnic group. This variable tests whether when the whites and the ethnic group have similar higher education levels, there will be less occupational stratification. It is expected that similar levels of education will result in equal occupational distribution.

- $\quad$ ECLF tests whether the overall level of education of the population of the economic area would influence the occupational differences. When the population is educated, prejudice and stereotyping are expected to be less and therefore there is more equal distribution of ethnic minorities in various occupations.

- $\quad$ DIF 40 $_{\mathrm{k}}$ tests the role of experience in determining occupational differences between the two groups tested. Experience and education are part of the human capital. Similar interethnic experience levels will lead to less stratification.

- $\quad \mathbf{P O C}_{\mathrm{k}}$ attempts to capture the effect of parents' occupation on the next generation. It tests socioeconomic status. The higher the level of education of the previous generation, the less the interethnic occupational stratification.

- $\quad \mathbf{M F C}_{\mathbf{k}}$ investigate the influence of the presence of children in the family on the amount of occupational differences between the ethnic groups. It is expected that families with children will experience less differences.

- $\quad$ PDEM $_{\mathbf{k}}$ reflects the density of the demographic group in a particular area. This variable has a twofold role. On the one hand, in EAs with high minority population, stratification results from stereotyping and the need for the same ethnic group in certain occupations. In EAs with a very small minority population, most ethnic/racial minorities may be recent immigrants who are professional or skilled workers; therefore, interethnic differences may narrow.

- $\quad$ POTH $_{\mathbf{k}}$ examine the effect of the presence of other minorities on the group tested in an economic area. This can be positive or negative depending on the socioeconomic level of the other minority groups.

- $\quad$ PSAME displays the influence of change in an area on prejudice. Areas that do not display change should be more traditional/conservative towards minorities. 
- $\quad$ CP tests the influence of crime rate on interethnic occupational segregation. EAs with high crime rates are expected to have more interethnic occupational segregation.

- GP attempts to capture the effect of the growth of the private sector employment. When the area experiences high growth, discrimination reduces productivity, therefore, ethnic stratification is expected to be reduced.

- $\quad \mathbf{X X}_{\mathrm{s}}$ shows whether an area specializes in occupations that involve a certain attribute. When competition is high, specialization is needed and discrimination reduces productivity. Therefore, EAs with high specialization would have less segregation.

- $\quad$ PG90 and GG investigate the influence of government employment practices on ethnic occupational differences. Government employment for females has been better than the private sector. Government employment should reduce interethnic occupational stratification.

- $\quad$ EF88 tries to establish whether large firms comply more to equal employment opportunity regulations. It is expected that large firms would hire people regardless of ethnicity and reduce stratification.

- $\quad$ PMIL90 military employment should reflect less discrimination. Areas with large military facilities are expected to present less ethnic occupational differences.

- $\quad$ CLF reflects the density of the population in an EA. Anonymity and emotional distance among people in highly dense EAs reduce interethnic occupational segregation.

- $\quad$ NORTH and SOUTH attempt to see the effect of migration. Different areas have different minorities.

\subsection{The Model}

Demographic and economic characteristics of EAs are tested to determine their significance in narrowing or increasing the highest minority dominated occupational attribute.

\subsection{Hypothesis}

Ceteris paribus, economic areas with higher educational levels, human capital accumulation, social status, and government protection of an ethnic minority, would have less ethnically segregated occupational attributes.

The following regression model is used to test the hypothesis.

$$
\mathrm{Aksi}=\beta \mathrm{s} 0+\sum_{\mathrm{j}=1}^{18} \beta \mathrm{sj} * \chi \mathrm{sji}+\varepsilon s \mathrm{si}
$$

where:

$\mathrm{A}_{\mathrm{ksi}}=$ Percent deviation of the tested ethnic group $\mathrm{k}$ from the white group in occupations with attribute $\mathrm{s}$ in Economic Area i

$\chi_{\mathrm{sji}}=$ Explanatory variable $\mathrm{j}$ for occupational attribute $\mathrm{s}$ in Economic Area $\mathrm{i}$

For each ethnic group, the occupational attribute with the highest positive percent deviation will be regressed. A total of six regressions will be run, one for each minority group.

\subsection{Empirical Procedure}


In Table 1, the percentages in bold reflect the highest positive percent deviation. African American and Hispanic males experience the widest difference from their white counterparts in occupations requiring "repetition". The difference between Asian and white males is the occupations requiring "part-time". For the females, in all three ethnic groups, the highest difference is found in occupations that require the attribute "mechanical ability".

For the above six occupational attributes, Ordinary-Least Squares (OLS) regression uses all the explanatory variables (table 2). Using t-statistic for the variables and F-test for the regression, the insignificant variables are dropped, one by one, until the final regression above $0.10 \mathrm{p}$-value includes only significant variables. The educational levels are kept in the regression. Breusch-Pagan test is used to determine whether heteroskedasticity is a problem in the data. White's procedure is used to correct for heteroskedasticity reestimating the standard errors (Greene, 1993). Standardized coefficients are used so that ranking of the most important factors in the regression is possible. Multicolinearity is expected due to the high intercorrelations of the data used. For determining multicollinearity, the condition number is used (Greene, 1993).

\subsection{Results}

The regression results show that the Hispanic and African American groups, for both males and females are influenced by similar explanatory variables and indicate a lot of similarities. However, the Asian group, both males and females are influenced by different variables. Table 3 shows the results of the six regressions. Table 4 is a summary of the results.

In the case of Hispanic and African American males, their level of higher education is the strongest variable reducing their dominance in occupations requiring repetition. This makes sense since occupations that require repetition do not require high levels of higher education. By acquiring higher education, these two groups will move out of these occupations and into occupations that require more advanced knowledge.

High labor demand in occupations requiring repetition, narrow the ethnic minority dominance. This is reasonable since when labor demand is high, employers are willing to hire non-traditional workers to satisfy the demand. In this case, white males are the non-traditional group.

The higher the educational levels of the civilian labor force in an EA, the less the labor segregation for the African American males. However, for the Hispanic males, the influence is the opposite. It actually increases the dominance of the Hispanic males into the occupations requiring repetition. In addition, more conservative/traditional areas place Hispanics into occupations requiring repetition. Hispanic males could be the victims of stereotyping.

High numbers of the minority group in the area, encourage more segregation in occupations requiring repetition and increase the percent deviation. This could be a result of stereotyping for both African and Hispanic American males. In an EA where the density of the minority group is high, blacks and Hispanics go into occupations which require repetition.

Females, regardless of minority group, have the highest percent domination in occupations which require mechanical ability. In the case of Hispanic and African American females, the presence of the minority group encourages their channeling into occupations that require mechanical ability. These women continue to find employment in traditionally minority held occupations in areas where the minority population group is high. Increasing their level of higher education improves their position and reduces the percent deviation. This is natural, as they would shift into other occupations, which require high levels of higher education. The overall educational level of the EA reduces the percent deviation because as the educational level of the EA increases, prejudice should diminish.

For Asian American Males, the most significant variable reducing the percent deviation for part time occupations is the level of experience the minority group has. The higher the experience level of the minority the more they would move out of part-time occupations and more into full-time. This is the only significant variable improv- 
ing the position of Asian American males.

In the case of Asian American females the presence of military facilities is the most significant variable widening the percent deviation. The higher the labor force participation in the military in an EA, the more Asian females would be involved in occupations that require mechanical ability. Apparently, a higher share of Asian women are engaged in blue-collar occupations in the vicinity of military bases. Asian females tend to be highly involved in factory positions. In addition, the higher the overall educational level of the area, the more Asian American females go into occupations requiring mechanical ability. Finally, the presence of large corporations in an EA helps the Asian American females in getting out of these occupations and into other less traditional for this group.

\section{Bibliography}

1. Amacher, Ryan C., and Holley H. Ulbrich. Principles of Economics. 4th ed. Cincinnati, Ohio: South-Western Publishing Co., (1989).

2. $\quad$ Bart, Landry. The New Black Middle Class. Berkeley: University of California Press, (1987): 74-75.

3. Becker, Gary S. The Economics of Discrimination. 2nd ed. Chicago: University of Chicago Press, (1971).

4. Bellinger, Robert. "Asian Engineers Hitting Glass Ceiling; Chinese, Indians Channeled Into R\&D.” Electronic Engineering Times. 806 (July 18, 1994): 89-90.

5. Billingsley, Andrew. Climbing Jacob's Ladder. The Enduring Legacy of African-America Families. New York: Simon and Schuster, Inc., (1992).

6. Cheng, Cliff. “Are Asian American Employees a Model Minority or Just a Minority?” Journal of Applied Behavioral Science. 33. (Sep 1997): 277-290

7. Clymer, Anne, and Elizabeth McGregor. "Matching Personal and Job Characteristics." Occupational Outlook_Quarterly 36 (Fall 1992): 7-23.

8. Dervarics, Charles. "Support Builds for Economic Stimulus Package: Measure may Include Increased Aid to Education." Black Issues in Higher Education. 18 (Jan. 31, 2002): 8.

9. Eff, Anthon Ellis. "Occupational Characteristics in Local Economies: Factors Explaining Intergender Differences." (Paper Presented at the Southern Regional Sciences Association Meeting, Orlando, Florida. (April 8, 1994).

10. Fairlie, Robert W. and Lori G. Kletzer. "Jobs lost, jobs regained: an analysis of black/white differences in job displacement in the 1980s." Industrial Relations. (October 1998): 460.

11. Feagin, Joe R. Racial and Ethnic Relations. 2nd ed. Englewood Cliffs, New Jersey: Prentice-Hall, Inc., (1984).

12. Flückiger Yves and Jacques Silber. "The Measurement of Segregation in the Labor Force. Physica-Verlag. Heidelberg. (1999).

13. Frey, William and Cheryl First. Investigating Change in American Society. Wadsworth Publishing Company, International Thomson Publishing Inc.: Belmont, CA. (1997).

14. Gardeck, Rosetta. "Racial Differences in Youth Employment." Monthly Labor Review. Vol. 124 (Aug. 2001): $51-67$.

15. Gilbert, Dennis and Joseph A. Kahl. The American Class Structure. Homewood, Illinois: The Dorsey Press, (1982).

16. Gill, Andrew M. "Incorporating the causes of occupational differences in studies of racial wage differentials."

17. Journal of Human Resources 29 (Winter 1994): 20-41.

18. . "The Role of Discrimination in Determining Occupational Structure." Industrial and Labor Relations Review 42 (July 1989): 610-23.

19. Glazer, Nathem. “American Diversity and 2000 Census.” Public Interest. 144 (Summer 2001): 3-18.

20. Glick, Peter, Korin Wilk, and Michele Perreault. "Images Of Occupations: Components of Gender and Status in Occupational Stereotypes.” Sex Roles. 32 (Oct 9, 1995): 565-582.

21. Greene, William H. Econometric Analysis. 2nd ed. New York: MacMillan Publishing Company, (1993).

22. Guadalupe, Patricia. “Aplace for More Hispanics?" Hispanic Business. 24 (March 2002): 56."Have Tech Businesses, will Travel." Business Week. 3615 (Feb. 8, 1999): 22B

23. Hakim, Catherine. Work LifeStyle Choices in the $21^{\text {st }}$ Century. Oxford University Press. (2000).

24. Heckman, James. "Detecting Discrimination.” Journal of Economic Perspective. 12 (Spring 1998): 101-116

25. Holzer, Harry and Keith Ihlanferdt. "Customer Discrimination and Employment Outcomes for Minority Workers." The Quarterly Journal of Economics. 113 (Aug. 1998): 835-67.

26. Jones, George H. "Minorities in the Scientific Workforce." Science. 296 (April 12, 2002): 217.

27. Kim, Pansuk, and Gregory B. Lewis. "Asian Americans in the Public Service: Success, Diversity, and discrimination." Public Administration Review 54 (May/June 1994): 285-290.

28. Kimenyi, Mwangi S. Economics of Poverty, Discrimination, and Public Policy. Cincinnati, Ohio: South-Western College Publishing, (1995).

29. Klein, Chris. "Asian-Americans Find Place in the Profession; Pacific Rim and Tech Booms Create Major Firms' Biggest Minority." The National Law Journal. 19 (Feb 17, 1997) 
30. Korenman, Sanders, and David Neumark. "Does Marriage Really Make Men More Productive?” Journal of Human Resources 26 (Spring 1991): 282-307.

31. Kulis, Stephen, Heather Shaw and Yimong Chong. "External Labor Markets and the Distribution of Black Scientists and Engineers in Academia.” Journal of Higher Education. 7 (March, 2000): 187.

32. Lehman, Nicholas. "Origin of the Black Underclass." Atlantic Monthly. (July, 1986).

33. Lutz, Martha E. "Images of Docility: Asian Women and the World-Economy." Edited by Joan Smith, Jane Collins, Terence K. Hopkins, and Akbar Muhammad. Racism, Sexism, and the World System. Westport, Connecticut: Greenwood Press, (1988): 57-74.

34. Mason, Sarah R. "Training Southeast Asian Women for Employment: Public Policies and Community Programs, 19751985. ” Asian Refugee Studies Occasional Community Papers, Number Four.

35. Minnesota University, Minneapolis: Southeast Refugee Studies. (1986).

36. Mitra, Aparna. "The Allocation of Blacks in Large Firms and Establishments and Black- White Wage Inequality in the U.S. Economy.” Sociological Inquiry. 69 (summer, 1999): 382-383.

37. Myers, Samuel L., Jr. "How Voluntary Is Black Unemployment and Black Labor Force Withdrawal?" Edited by Steven Shulman and William Darity, Jr. The Question of Discrimination: Racial Inequality in U.S.

38. Labor Market. Middletown, Connecticut: Wesleyan University Press, (1989): 81-108.

39. Philips, Robert L., Paul J. Andrisani, Thomas N. Daymont, and Curtis L. Gilroy. "The Economic Return to Military Service: Race-Ethnic Differences.” Social Science Quarterly. 73 (June 1992): 340-359.

40. Prywes, Ruth, W. The United States Labor Force: A descriptive Analysis. Quorum Books: West Port, Connecticut. (2000).

41. Sakamoto, Arthur and Jessie M. Tzeng. “A Fifty-Year Perspective On The Declining Significance Of Race In The Occupational Attainment Of White And Black Men.” Sociological Perspectives. 42 (Summer, 1999): 157-159.

42. Schoepfle, Gregory K., Jorge F. Perez-Lopez, and Eric Griego. "The Underground Economy in the United States." Cooperative Project: Secretaria del Trabajo y Prevision Social de Mexico and U.S. Department of Labor, Office of International Affairs. (1992).

43. Segal, David R., and Naomi Verdugo. "Demographic Trends and Personnel Policies as Determinants of the Racial Composition of the Volunteer Army." Armed Forces \& Society. 20 (summer, 1994): 619-632.

44. Smith, James. "Race and Ethnicity in the Labor Markets." In American Becoming: Racial Trends and their Consequences. Vol. II. Editors: Neil Smelser, William Wilson and Faith Mitchell. National Research Council. National Academy Press: Washington, DC. (2001).

45. Smith, James P., and Finis R. Welch. "Race and Poverty: a Forty-Year" American Economic Review. 77 (May 1987): 152-158.

46. $\quad$ Smith, James P., and Finis R. Welch. "Black Economic Progress after Myrdal." Journal of Economic Literature 28 (June 1989): 519-562.

47. Sokoloff, Natalie. Black Women and White Women in the Professions: Occupational Segregation by Race and Gender 1960-1980. New York: Routledge. (1992).

48. Sorensen, Elaine. "The Wage Effects of Occupational Sex Segregation: Review and New Findings." In Hill Anne and Mark Killingsworth, eds. Colloquium on Comparable Worth. Cornell University. Comparable Work: Analysis and Evidence. Ithaca: ILR Press. (1989)..Comparable Worth: Is it a Worthy Policy? Princeton: Princeton University Press. (1994).

49. Stoll, Michael and Steven Raphael. "Racial Differences in Spatial Job Search Patterns: Exploring the Causes and Consequences.” Economic Geography. 76 (July, 2000): 201

50. Tienda, Marta and Lief Jensen. "Poverty and Minorities: A Quarter Century Profile of Color and Socioeconomic Disadvantage." (Paper Delivered at the Conference on "Poverty and Social Policy: The Minority

51. Experience." Arlie, Virginia, (Nov. 5-7, 1986).

52. Tomkiewicz, Joseph and Tope Adeyemi-Bello. "The Impact of Perceptions and Stereotypes on the Managerial

53. Mobility of African Americans.” The Journal of Social Psychology. 138 (1998): 88-92.

54. U. S. Bureau of the Census. Current Population Reports: Population Projections The United States, by Age, Sex, race, and Hispanic Origin, 1992-2050. Washington, DC: U. S. Government Printing Office, (1992a).Current Population Reports: The Asian and Pacific Islander Population in the United States, March_1991 and 1990. Washington, DC: U. S. Government Printing Office, (1992b).

55. U.S. Bureau of Economic Analysis: Economics and Statistics Administration. Regional Economic Information_System 1969-1992. Washington, DC: U. S. Government Printing Office, (May 1994).

56. U.S. Bureau of the Census. 2000 Educational Attainment of the Population 18 years and Over by Age, Sex, Race_and Hispanic Origin. (March 2000).

57. U.S. Bureau of the Census. 1990 Census of Population and Housing Summary Tape File 3C. Washington, DC: U. S. Government Printing Office, (May 1993).

58. 1990 Census of Population and Housing: Equal Employment Opportunity File. Washington, DC: U.S. Government Printing Office, (January 1993). 
59. ___ __ Statistical Abstract of the United States: 1990 110th ed. Washington, DC: U.S. Government Printing Office, (1990).

60. U.S. Bureau of the Census. Statistical Abstract of the United States: 1994 114th ed. Washington, DC: U.S. Government Printing Office, (1994).. USA Counties. Washington, DC: U. S. Government Printing Office, June (1992).

61. U.S. Commission on Civil Rights. Success of Asian Americans: Fact or Fiction? Washington, DC: U.S. Government Printing Office, (1992).

62. U.S. Department of Commerce. Bureau of Economic Analysis, Regional Economic Analysis Division. "BEA Economic Area Projection and Income, Employment and Population to the Year 2000." Survey of Current Business 70 (November 1990): 39-41.

63. U.S. Immigration and Naturalization Service. 1975 Annual Report. Washington, DC: U.S. Printing Office, (1975): 6264.

64. U.S. Department of Labor. Bureau of Labor Statistics. http://data.bls.gov/cgi-bin/surveymost . (2002).

65. Wellner, Stein. "New Data on Segregation Coming Soon.” Forecast. 22 (August, 2002): 11.

66. Wellner, Stein. "Los Otros: New Research Challenging the Size of the Census Bureau's "Other Hisanic" Category Reveals That There May be More Hispanics Who Identify wit Their Roots and Country of Origin than Previously Reported." Forecast. 22 (July, 2002): 1-4.

67. Xin, Kathring R. "Asian American Managers: An Impression Gap? An Investigation of Impression Management and Supervisor-Subordinate Relationships.” Journal of Applied Behavioral Science. 33 (Sep 1997): 335-355.

Table 1: Percent Deviation Between the Ethnic Group Tested and Whites

\begin{tabular}{|l|c|c|c|c|c|c|}
\hline Occupational Attributes & $\begin{array}{c}\text { Hispanic } \\
\text { Males }\end{array}$ & $\begin{array}{c}\text { Black } \\
\text { Males }\end{array}$ & $\begin{array}{c}\text { Asian } \\
\text { Males }\end{array}$ & $\begin{array}{c}\text { Hispanic } \\
\text { Females }\end{array}$ & $\begin{array}{c}\text { Black } \\
\text { Females }\end{array}$ & $\begin{array}{c}\text { Asian } \\
\text { Females }\end{array}$ \\
\hline Research and Compiling & $-53 \%$ & $-48 \%$ & $37 \%$ & $-32 \%$ & $-29 \%$ & $5 \%$ \\
Analyzing and evaluating & $-52 \%$ & $-50 \%$ & $12 \%$ & $-36 \%$ & $-28 \%$ & $0 \%$ \\
Trouble shooting & $-32 \%$ & $-29 \%$ & $-7 \%$ & $-22 \%$ & $-21 \%$ & $-5 \%$ \\
Artistic Expression & $-48 \%$ & $-57 \%$ & $-9 \%$ & $-43 \%$ & $-68 \%$ & $-22 \%$ \\
Instructing & $-54 \%$ & $-45 \%$ & $14 \%$ & $-41 \%$ & $-26 \%$ & $-14 \%$ \\
Treating and Advising & $-57 \%$ & $-36 \%$ & $18 \%$ & $-39 \%$ & $3 \%$ & $-11 \%$ \\
Supervising & $-43 \%$ & $-46 \%$ & $-23 \%$ & $-31 \%$ & $-35 \%$ & $-22 \%$ \\
Persuading & $-49 \%$ & $-52 \%$ & $-25 \%$ & $-31 \%$ & $-38 \%$ & $-26 \%$ \\
Public Contact & $-30 \%$ & $-24 \%$ & $-1 \%$ & $-21 \%$ & $-16 \%$ & $-14 \%$ \\
Mechanical Ability & $-1 \%$ & $-16 \%$ & $-29 \%$ & $80 \%$ & $55 \%$ & $85 \%$ \\
Operating Vehicle & $27 \%$ & $20 \%$ & $-54 \%$ & $30 \%$ & $3 \%$ & $-55 \%$ \\
Repetitious & $52 \%$ & $71 \%$ & $10 \%$ & $29 \%$ & $22 \%$ & $17 \%$ \\
Mobility & $4 \%$ & $-10 \%$ & $-51 \%$ & $20 \%$ & $6 \%$ & $-36 \%$ \\
Physical Stamina & $28 \%$ & $16 \%$ & $-46 \%$ & $44 \%$ & $39 \%$ & $9 \%$ \\
Part Time & $29 \%$ & $39 \%$ & $46 \%$ & $6 \%$ & $17 \%$ & $6 \%$ \\
Irregular Hours & $5 \%$ & $3 \%$ & $5 \%$ & $10 \%$ & $12 \%$ & $10 \%$ \\
\hline Higher Education & $-64 \%$ & $-54 \%$ & $59 \%$ & $-55 \%$ & $-37 \%$ & $55 \%$ \\
\hline
\end{tabular}

Source: U.S. Bureau of the Census. 1990 Census of Population and Housing: Equal Employment Opportunity File: Washington, DC Government Printing Office, January 1994.

Final row: Represents the percent deviation for higher education levels

Nagative values: Attribute is predominantly white

Positive values: Attribute is predominantly performed by the ethnic group tested 


\begin{tabular}{|c|c|c|}
\hline $\begin{array}{l}\text { Explanatory } \\
\text { Variables }\end{array}$ & Description & Source \\
\hline $\mathrm{EDDIF}_{\mathrm{K}}$ & $\begin{array}{l}\text { Percent difference between the percent of ethnic group } \mathrm{K} \text { and the percent of } \\
\text { whites who have } 4 \text { or more years of college education }\end{array}$ & EEOF \\
\hline ECLF & Percent of civilian labor force with four years or more of college education & EEOF \\
\hline${ }^{\mathrm{DIF}} 40_{\mathrm{K}}$ & $\begin{array}{l}\text { Percent difference between 1)the college educated percent of ethnic group } \\
\text { k's workers who are over } 39 \text { years of age; } 2 \text { ) the college educated percent of } \\
\text { over } 39 \text { white workers }\end{array}$ & EEOF \\
\hline $\mathrm{POC}_{\mathrm{K}}$ & $\begin{array}{l}\text { Percent of all workers in ethnic group K over } 39 \text { years of age with college } \\
\text { degree }\end{array}$ & EEOF \\
\hline $\mathrm{MFC}_{\mathrm{K}}$ & $\begin{array}{l}\text { Percent of ethnic group K's households consisting of married couples with } \\
\text { children }\end{array}$ & STF3 \\
\hline $\mathrm{PDEM}_{K}$ & Percent of civilian labor force that belongs to ethnic group $\mathrm{K}$ & EEOF \\
\hline $\mathrm{POTH}_{K}$ & Percent of CLF consisting of other non white ethnic groups & EEOF \\
\hline PSAME & Percent of over age 5 population living in the same house since 1985 & STF3 \\
\hline $\mathrm{CP}$ & Serious crimes per 1000 population (average 1980-84) & USAC \\
\hline GP & $\begin{array}{l}\text { Growth rate of private sector employment 1969-89 (equivalent years in the } \\
\text { business cycle) }\end{array}$ & REIS \\
\hline $\mathrm{XX}_{\mathrm{S}}$ & Percent of civilian labor force in occupations possessing attribute & EEOF \\
\hline PG90 & Percent of 1990 employment in government civilian jobs & REIS \\
\hline GG & $\begin{array}{l}\text { Growth rate of government civilian employment 1969-89 (equivalent years } \\
\text { in the business cycle }\end{array}$ & REIS \\
\hline EF88 & Employees per firm 1988 & USAC \\
\hline PMIL90 & Percent of labor force in the military & EEOF \\
\hline CLF & Civilian labor force & EEOF \\
\hline NORTH & Dummy variable for the North East region of the U.S. & Dummy \\
\hline SOUTH & Dummy variable for the South East region of the U.S. & Dummy \\
\hline \multicolumn{3}{|c|}{$\begin{array}{l}\text { Sources: } \\
\text { REIS: U.S. Bureau of Economic Analysis: Economics and Statistics Administration. Regional Economic Information System 1969-1992. Wash- } \\
\text { ington DC: Government Printing Office, May } 1994 . \\
\text { EEOF: U.S. Bureau of the Census. } 1990 \text { Census of Population and housing: Equal Employment_Opportunity File Washington DC: Government } \\
\text { Printing Office, January } 1994 . \\
\text { STF3: U.S. Bureau of the Census. } 1990 \text { Census of Population and Housing Summary Tape File 3C Washington DC: Government Printing Of- } \\
\text { fice, May } 1993 \text {. } \\
\text { USAC: U.S. Bureau of the Census. USA Counties. Washington DC: Government Printing Office, June } 1992 .\end{array}$} \\
\hline
\end{tabular}




\begin{tabular}{|c|c|c|c|c|c|c|}
\hline \multicolumn{7}{|c|}{$\begin{array}{c}\text { Table 3: Regression results for Occupational Attributes with the Highest Positive } \\
\text { Percent Deviation for Each Ethnic Group }\end{array}$} \\
\hline Minority Group & $\begin{array}{c}\text { African } \\
\text { American } \\
\text { Males }\end{array}$ & $\begin{array}{l}\text { Hispanic } \\
\text { Males }\end{array}$ & $\begin{array}{l}\text { Asian Ameri- } \\
\text { can Males }\end{array}$ & $\begin{array}{c}\text { African } \\
\text { American } \\
\text { Females }\end{array}$ & $\begin{array}{l}\text { Hispanic Fe- } \\
\text { males }\end{array}$ & $\begin{array}{l}\text { Asian Ameri- } \\
\text { can Females }\end{array}$ \\
\hline $\begin{array}{l}\text { Highest Percent } \\
\text { Deviation }\end{array}$ & 71 & 52 & 46 & 55 & 80 & 85 \\
\hline $\begin{array}{l}\text { Occupational } \\
\text { Attribute }\end{array}$ & Repetitious & Repetitious & Part Time & $\begin{array}{l}\text { Mechanical } \\
\text { Ability }\end{array}$ & $\begin{array}{l}\text { Mechanical } \\
\text { Ability }\end{array}$ & $\begin{array}{l}\text { Mechanical } \\
\text { Ability }\end{array}$ \\
\hline $\begin{array}{l}\text { Explanatory } \\
\text { Variable }\end{array}$ & $\mathrm{EDDIF}_{\mathrm{K}}$ & $\mathrm{EDDIF}_{\mathrm{K}}$ & DIF $40_{K}$ & $\mathrm{PDEM}_{\mathrm{K}}$ & $\mathrm{PDEM}_{\mathrm{K}}$ & PMIL90 \\
\hline $\begin{array}{l}\text { Standardized } \\
\text { Coefficient }\end{array}$ & $\begin{array}{l}-0.715 \\
(0.00)\end{array}$ & $\begin{array}{r}-0.484 \\
(0.00)\end{array}$ & $\begin{array}{l}-0.398 \\
(0.00)\end{array}$ & $\begin{array}{l}0.488 \\
(0.00)\end{array}$ & $\begin{array}{l}0.381 \\
(0.00)\end{array}$ & $\begin{array}{l}0.462 \\
(0.00)\end{array}$ \\
\hline $\begin{array}{l}\text { Explanatory } \\
\text { Variable }\end{array}$ & $\mathrm{XX}_{\mathrm{S}}$ & ECLF & & EDDIF $_{K}$ & EDDIF $_{K}$ & ECLF \\
\hline $\begin{array}{l}\text { Standardized } \\
\text { Coefficient }\end{array}$ & $\begin{array}{l}0.557 \\
(0.00)\end{array}$ & $\begin{array}{l}0.382 \\
(0.00)\end{array}$ & & $\begin{array}{l}-.144 \\
(0.10)\end{array}$ & $\begin{array}{r}-0.371 \\
(0.00)\end{array}$ & $\begin{array}{l}0.361 \\
(0.00)\end{array}$ \\
\hline $\begin{array}{l}\text { Explanatory } \\
\text { Variable } \\
\end{array}$ & ECLF & $\operatorname{PSAME}_{\mathrm{K}}$ & & ECLF & CLF & EF88 \\
\hline $\begin{array}{l}\text { Standardized } \\
\text { Coefficient }\end{array}$ & $\begin{array}{r}-0.293 \\
(0.00)\end{array}$ & $\begin{array}{l}0.354 \\
(0.00)\end{array}$ & & $\begin{array}{r}-0.143 \\
(0.00)\end{array}$ & $\begin{array}{l}0.327 \\
(0.00)\end{array}$ & $\begin{array}{r}-0.286 \\
(0.00)\end{array}$ \\
\hline $\begin{array}{l}\text { Explanatory } \\
\text { Variable } \\
\end{array}$ & $\mathrm{PDEM}_{\mathrm{K}}$ & $\mathrm{PDEM}_{\mathrm{K}}$ & & & & PG90 \\
\hline $\begin{array}{l}\text { Standardized } \\
\text { Coefficient }\end{array}$ & $\begin{array}{l}0.285 \\
(0.00)\end{array}$ & $\begin{array}{l}0.282 \\
(0.00)\end{array}$ & & & & $\begin{array}{l}-0.218 \\
(0.05)\end{array}$ \\
\hline $\begin{array}{l}\text { Explanatory } \\
\text { Variable }\end{array}$ & $\mathrm{POC}_{\mathrm{K}}$ & EF88 & & & & \\
\hline $\begin{array}{l}\text { Standardized } \\
\text { Coefficient }\end{array}$ & $\begin{array}{l}0.217 \\
(0.00) \\
\end{array}$ & $\begin{array}{l}0.196 \\
(0.00) \\
\end{array}$ & & & & \\
\hline $\mathbf{R}$ squared & 0.639 & 0.736 & 0.143 & 0.323 & 0.590 & 0.367 \\
\hline F-test & $\begin{array}{l}{[6,176]} \\
51.9980\end{array}$ & $\begin{array}{l}{[11,171]} \\
43.4578\end{array}$ & $\begin{array}{l}{[3,179]} \\
10.0228\end{array}$ & $\begin{array}{l}{[6,176]} \\
13.9902\end{array}$ & $\begin{array}{l}{[4,174]} \\
62.7713\end{array}$ & $\begin{array}{c}{[12,162]} \\
73.8491\end{array}$ \\
\hline$P$-value & 0.00000 & 0.00000 & 0.00000 & 0.00000 & 0.00000 & 0.00000 \\
\hline Breush-Pagan & 120.259 & 55.599 & 52.995 & 75.041 & 32.058 & 57.683 \\
\hline $\begin{array}{l}\text { Condition Num- } \\
\text { ber }\end{array}$ & 71.75 & 81.86 & 12.88 & 25.97 & 13.33 & 37.35 \\
\hline
\end{tabular}

Standardized Coefficient:: Number in parentheses is the P-value of the respective beta coefficient 


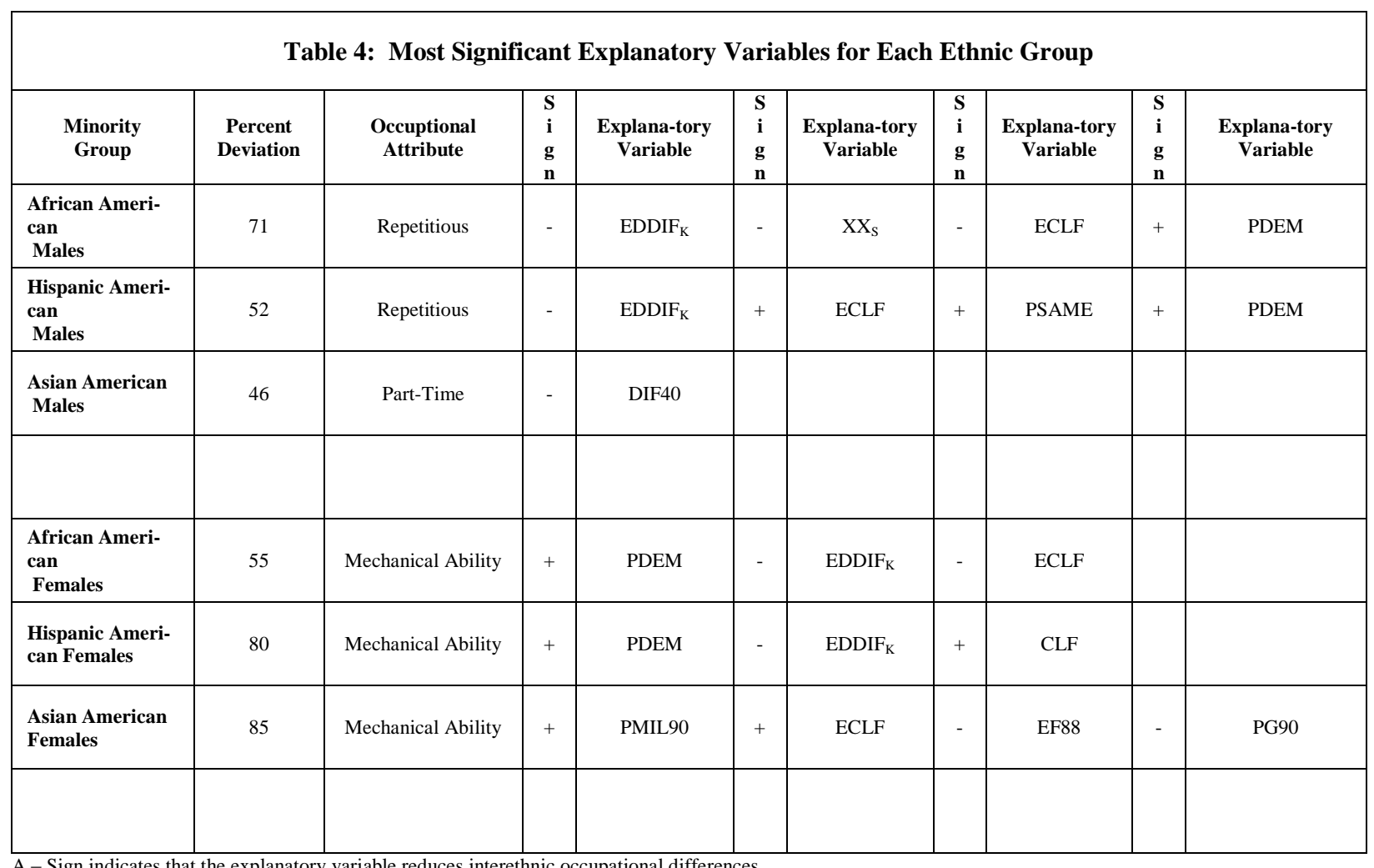

A - Sign indicates that the explanatory variable reduces interethnic occupational differences.

A + Sign indicates that the explanatory variable increases interethnic occupational differences

Table 5: Percentage of Educational Attainment of the U. S. Labor Force by Ethnic Origin

\begin{tabular}{|l|c|c|c|c|c|}
\hline & Population & Baccelaureate & Masters & Professional & Doctorate \\
\hline White Males & $73.97 \%$ & $18.08 \%$ & $6.00 \%$ & $2.16 \%$ & $1.67 \%$ \\
\hline African American Males & $10.73 \%$ & $10.16 \%$ & $3.17 \%$ & $0.51 \%$ & $0.36 \%$ \\
\hline Hispanic American Males & $10.78 \%$ & $6.14 \%$ & $1.68 \%$ & $0.56 \%$ & $0.49 \%$ \\
\hline Asian American Males & $3.87 \%$ & $25.23 \%$ & $10.07 \%$ & $2.64 \%$ & $3.94 \%$ \\
\hline TOTAL Males & $99.35 \%$ & $17.18 \%$ & $5.37 \%$ & $1.82 \%$ & $1.48 \%$ \\
\hline White Females & $72.87 \%$ & $16.80 \%$ & $5.67 \%$ & $0.85 \%$ & $0.61 \%$ \\
\hline African American Females & $12.31 \%$ & $10.32 \%$ & $3.86 \%$ & $0.46 \%$ & $0.27 \%$ \\
\hline Hispanic American Females & $10.17 \%$ & $6.48 \%$ & $1.85 \%$ & $0.55 \%$ & $0.31 \%$ \\
\hline Asian American Females & $3.92 \%$ & $27.37 \%$ & $6.70 \%$ & $2.02 \%$ & $1.44 \%$ \\
\hline TOTAL Females & $99.27 \%$ & $15.31 \%$ & $5.08 \%$ & $0.81 \%$ & $0.57 \%$ \\
\hline TOTAL & & $15.72 \%$ & $5.22 \%$ & $1.30 \%$ & $1.01 \%$ \\
\hline
\end{tabular}

Source: U.S. Census Bureau. "Educational Attainment of the Population 18 years and Over, by Age, Sex, Race and Hispanic Origin" Internet Release Date: December 19, 2000. 